\title{
Health evaluation of penguins (Sphenisciformes) following mortality in the Falklands (South Atlantic)
}

\author{
I. F. Keymer ${ }^{1, *}$, H. M. Malcolm² ${ }^{2}$ A. Hunt ${ }^{3}$, D. T. Horsley ${ }^{4}$ \\ ${ }^{1}$ The Old Smithy, The Green, Edgefield, Melton Constable, Norfolk NR24 2AL, United Kingdom \\ ${ }^{2}$ Centre for Ecology \& Hydrology, CEH Monks Wood, Abbots Ripton, Huntingdon, Cambridgeshire E28 2LS, United Kingdom \\ ${ }^{3}$ Ministry of Agriculture, Fisheries \& Food, Veterinary Laboratories Agency, The Elms, College Road, Sutton Bonington, \\ Loughborough, Leicestershire LE12 5RB, United Kingdom \\ ${ }^{4}$ The Department of Biology, Gresham's School, Holt, Norfolk NR25 6EA, United Kingdom
}

\begin{abstract}
In the Falklands, heavy mortality of rock-hopper penguins Eudyptes chrysocome occurred during the 1985-86 breeding season. Starvation was diagnosed as the primary cause of death, possibly caused by a shortage of euphausiid crustaceans (krill) due to unusual meterological conditions. 'Puffinosis' may possibly have been a contributory factor; otherwise no conclusive evidence of infectious disease or toxicosis was found and also no evidence of radioactive contamination. In the 1986-87 breeding season no unusual mortality occurred, but 99 apparently healthy penguins were examined, i.e., rockhoppers Eudyptes chrysocome syn E. crestatus, gentoos Pygoscelis papua and Magellanics Spheniscus magellanicus. Full necropsies were carried out on 54. Tissue examinations were made for cadmium, copper, iron, manganese, mercury, lead and zinc. High tissue cadmium concentrations found in healthy birds in 1987 were similar to those in penguins which died in 1986, and therefore not considered to be of pathological significance. Although there has been no repetition of the unusually hot 1985-86 breeding season in the Falklands, penguins and other seabirds have had fluctuating breeding successes since then. The precise cause, including the roles of meteorological conditions and overexploitation of some forms of prey species, is unclear.
\end{abstract}

KEY WORDS: Penguins $\cdot$ Falklands $\cdot$ Puffinosis $\cdot$ Metals $\cdot$ Cadmium $\cdot$ Parasites $\cdot$ Euphausiids (Krill)

\section{INTRODUCTION}

During the 1985-86 breeding season there was heavy and widespread mortality of rockhopper penguins Eudyptes chrysocome syn E. crestatus in the Falkland Islands, South Atlantic ocean (Keymer 1987, Woods 1988). Richard Hill (pers. comm. 1986) also reported that during this period gentoo penguin Pygoscelis papua colonies on the Jason Islands in the Falklands 'had been depleted by at least a third'. Keymer (1987) briefly outlined the methods used in investigating the mortality and recorded some preliminary results and conclusions. Since then more detailed results have been published, i.e., haematological

*E-mail: ianjan@ukf.net
(Hawkey et al. 1989) and biochemical (Ghebremeskel et al. 1989a,b, Williams et al. 1989) results; as well as investigations on the possibility of botulism (Smith et al. 1987). This paper completes the toxicological and parasitological results, but also records unpublished data and results of histopathological examinations. In anticipation of the mortality reccurring in the 1986-87 breeding season, the senior and junior authors visited the Falklands during the month of February 1987. However, with a few exceptions, penguins appeared healthy. This presented an excellent opportunity to obtain data on haematology, biochemistry and base line values for tissue concentrations of metals from healthy birds. Since then a similar health evaluation of free-living rockhoppers has been carried out in Argentina by Karesh et al. (1999). 
Keymer (1987) diagnosed starvation as the primary cause of death of rockhoppers in 1986 and tentatively concluded that this may have been caused by a shortage of krill (euphausiid crustaceans) at the time of the penguins' post-breeding moult. Thompson (1993) found that euphausiid krill and hyperid amphipods plus small squid, notably Gonatus antarcticus, were the main constituents of the diet during egg laying, incubation and whilst rearing young. The southern summer of 1985-86 was unusually long and hot in the Falkland Islands and according to Boersma (1987) was analogous to the Pacific El Niño Southern Oscillation (ENSO). It was decided therefore to delay publication of further investigations, including toxicological results, in case the meteorological conditions were repeated in the Falklands, in the hope that it would then be possible to test the hypothesis that shortage of euphausiid crustaceans (krill) was associated with the unusually warm weather. The Pacific ENSO of 1982-83 was 'the strongest of the century' and weaker ones occurred in 1986-87 and 1991-93 (McPhaden 1994). A further severe one occurred in 1997-98. However, there has been no repetition of an unusually hot summer in the Falklands area since 1985-86. In addition to more frequent ENSOs possibly adversely affecting world climate, new threats to Falkland Island birds, especially penguins, have emerged. These include tourism, fires and oil exploration. In fact there was an oiling incident involving penguins in August 1998 (M. Bingham pers. comm.).

\section{MATERIALS AND METHODS}

Localities and numbers of penguins examined between 6 and 28 February 1987. A licence ('The Wild Animals and Birds Protection Ordinance, 1964') was granted by the Falkland Islands Government to take tissues post-mortem from penguins after 15 February, 1987 'when the season's young have left the colonies'. Prior to that date, however, blood sampling was allowed. Tissues were taken from birds on New Island (2 visits), East Falkland (Gypsy Cove near Stanley and Bertha's Beach near Mount Pleasant) and the islands of Saunders, Bleaker and Sea Lion. On Kidney Island no tissues were taken. In total, specimens were taken from 99 penguins; 67 rockhoppers, 12 Magellanic Spheniscus magellanicus and 20 gentoos.

Recording methods in the field. The details of each bird were recorded on cards, which were designed to reduce writing to the minimum. When not in use in the field, they were kept in a plastic bag for protection against the weather.

Equipment. For field work, a practitioner's case was used to carry specimen bottles, reagents, syringes, needles, surgical gloves, dissecting instruments, microscope slides and first aid equipment. Containers for haematological equipment, including minihaematocrit centrifuge and miniphotometer (Hawkey et al. 1989), camera and other photographic equipment, were carried in rucksacks, because vehicles could not be used.

Some laboratory work was carried out at the Veterinary Department in Stanley; this included some of the necropsies and centrifugation of blood samples.

Capture of live penguins. These were stalked on foot and caught using a long-handled net. Prior to 16 February, 45 were released after examination, because many young birds were still being fed by their parents. After that date 54 were killed for necropsy.

Clinical examination, restraint and blood sampling. The plumage of each bird was examined for evidence and stage of moult, parasitic infestations and abnormalities such as oiling. The eyes and other areas of the body were examined for pox, trauma or other lesions. The skin of the feet and legs were examined for lesions of 'puffinosis'. When examinations were completed, the penguin was restrained in a specially designed holder made of plastic material in the form of a tube open at one end. The penguin was inserted head first and the feet and legs restrained using the purse string method. The tube had a slit in the side to enable the bird to breath, and which was large enough for a flipper to be withdrawn to facilitate bleeding from the brachial vein.

Unlike most birds, the cutaneous ulnar vein of the wing is not discernible in the flipper of penguins, but the brachial vein can be readily raised by pressure of the fingers or thumb in the axilla close to the thorax (Samour et al. 1983). In most instances, blood could be easily withdrawn using a disposable syringe and needle $(0.6 \times 16 \mathrm{~mm}, 23$ gauge $)$.

Body measurements. After clinical examination of rockhoppers, the length, depth and width of the beak were measured using standard calipers. This was done in order to assist in sexing (Strange 1982). Each rockhopper was also weighed using a spring balance whilst still in the plastic holder.

Post-mortem examination of penguins in 1987. After being killed by chloroform inhalation, 32 rockhoppers, 12 Magellanics and 10 gentoos were examined on the day of death. The following tissues were taken from all birds and examined grossly for evidence of infectious and non-infectious diseases: skin and feathers, liver, kidney, spleen, bone (femur), brain, thyroid, stomach (proventriculus/gizzard), heart, pancreas, duodenum, bursa of Fabricius, lung, lumbo-sacral nerve and gonads.

Microbiological examinations. As bacteriological (including examination for Chlamydia psittaci), fungal and virological examinations had been carried out 
with insignificant results on rockhoppers which died in 1986, these tests were not repeated on apparently healthy birds in 1987.

Examinations for parasites. The alimentary tract, liver and other organs of all 15 rockhoppers received in 1986 were examined. In 1987, peripheral blood smears from the brachial vein of 94 penguins were fixed in absolute methanol and stained with Giemsa. Helminths collected from the alimentary tract were cleaned by shaking vigorously in normal saline to remove mucus or other detritus prior to being preserved in $70 \%$ ethyl alcohol. Ectoparasites were fixed in $70 \%$ ethyl alcohol.

Examination for 'puffinosis'. Foot lesions from 3/15 rockhoppers received in 1986 were examined by electron microsocopy (EM). Histopathological examination of foot lesions was carried out on 3 of the 1986 rockhoppers and 1 in 1987 from Sea Lion Island.

Toxicological examinations. Analyses were carried out for the following metal contaminants: copper, zinc, cadmium, mercury, lead, chromium, manganese and iron.

Tissues (previously frozen) were taken for analyses from 15 rockhoppers received in 1986, namely liver, kidney, brain, bone (femur), and feathers. The same tissues were collected for metal (except chromium) analyses from 3 species of penguins in 1987; 32 rockhoppers, 12 Magellanics and 10 gentoos (see Table 1 and 'Results: Toxicology'). In the Falklands the tissues were preserved in $10 \%$ formol saline, a specimen of which was kept so it could be analysed for possible metal contamination. This method had to be used, because of lack of deep freezer facilities and the necessity of transporting fixed tissues to the United Kingdom (UK) under the conditions imposed by the Importation of Animal Pathogens Order, 1980.

The samples analysed at the Institute of Terrestrial Ecology, and at the Sutton Bonington Veterinary Investigation Centre were digested in nitric acid and analysed using flame atomic absorption spectroscopy with the exception of mercury, which was analysed using cold vapour atomic absorption spectroscopy, as described by Osborn (1979).

Histopathological examinations. Various tissues were taken at necropsy from 15 rockhoppers received in 1986 and from 32 rockhoppers, 12 Magellanics and 10 gentoos that were sacrificed in 1987. Tissues were fixed in $10 \%$ formol saline and included all or some of those listed in 'Microbiological examinations' above, depending on the circumstances. Tissues were embedded in paraffin wax, sectioned and stained by standard methods using Haematoxylin and Eosin. When indicated, some tissues were also stained with Gram's stain for bacteria, Perls' stain for iron, and Ziehl-Neelsen for acid fast intra-nuclear inclusions indicative of lead poisoning. Histopathological examination of tissues from the penguins of 1987 was selective and not carried out on all of the healthy birds.

Examination for radioactivity. Pooled pectoral muscle tissue from rockhoppers received in 1986 was submitted to the Ministry of Agriculture, Fisheries and Food, Central Veterinary Laboratory, Weybridge, Surrey, UK, for examination. The muscle was examined for gamma-emitting radionuclides using a standardised germanium spectrometer (Tony Dell pers. comm.).

\section{RESULTS}

\section{History}

Enquiries in 1987 revealed no evidence of unusual mortality similar to that affecting the rockhoppers in the 1985-86 breeding season (Keymer 1987). When visiting New Island in 1987, considerable numbers of rockhopper penguin skeletons and remains were still visible in the breeding colonies. Enquiries revealed no evidence of oiling, fish net mortality such as that caused by driftnets described by Ryan \& Cooper (1991), dinoflagellate poisoning, mortality due to toxic agents, radioactivity, unusually heavy predation (except when birds became weak and started to die) or direct effects associated with fishing in Falkland waters.

\section{Clinical examinations}

Most of the rockhoppers examined in 1987 were found to be in moderate to good bodily condition and only 4 sick birds were found. These were destroyed and examined. Two were found on New Island and singles from Saunders and Sea Lion Islands. Two injured birds were found and killed on New Island. No signs of oil contamination were found.

\section{Body measurements}

Bill measurements were confirmed to be only an approximate guide to sexing, as reported by Strange (1982). The details are available but will not be discussed here.

Weights were used as a rough guide to bodily condition. It was not possible to age the penguins accurately. In the rockhoppers (adults and subadults) that were received for necropsy during the 1986 outbreak of mortality, weights ranged from 1.17 to $2.34 \mathrm{~kg}$ (mean $1.67 \mathrm{~kg}$ ). This compared with a range of 2.1 to $4.8 \mathrm{~kg}$ (mean $3.45 \mathrm{~kg}$ ) in apparently healthy (but moulting) adult and subadult rockhoppers caught in 1987. 


\section{Gross pathology and histopathology of rockhoppers in 1986}

A variety of lesions was encountered in all these penguins, but the majority was indicative of starvation and others were of a secondary nature. No injuries were found, except that 1 bird had a ruptured liver. All the birds were thin, showing varying degrees of atrophy of the pectoral muscles and virtual absence of body fat. In most birds the stomachs were empty except for bile-stained fluid, although squid beak remains and/or feathers were present in a few and nematodes in 1 . In 4 penguins the lungs were congested and showed a degree of consolidation. There was oedema of the pectoral muscles in 1 bird and the heart muscle appeared pale. Two showed subepicardial oedema of the cardiac muscle of the coronary groove of the heart, indicative of a nutritional cardiomyopathy; histopathological examination of muscle tissue from 8 birds provided further evidence to support this view. The pectoral and leg muscles were most severely affected and the heart to a much lesser extent. Lesions varied from early degenerative fragmentation of muscle fibres, lysis with granule formation, loss of striations and necrosis. In 10/12 birds hepatic haemosiderosis was present, being moderate to severe in 9, although it had not progressed to the stage of haemochromatosis. Haemosiderin was found throughout the parenchyma both in the hepatocyte cytoplasm and in Kupffer's cells. In 3 penguins additional liver lesions were found. In 1 bird these may have been caused by helminth infestation apparently involving the bile ducts (see 'Parasites') and consisted of encapsulated necrotic areas associated with mononuclear cell infiltration, especially small lymphocytes. In the other 2 birds inflammatory cell infiltration was of an insignificant nature. No intra-nuclear inclusions were detected in the livers or kidneys of 12/14 penguins examined. However, examination of the kidneys was hindered by autolytic changes, although in most birds these were not severe. Lesions were variable and of a non-specific type. Renal or ureteral lesions were present in 7/12 birds. In 1 penguin unusual giant cell formation involving the renal tubules was present in some areas. In 3 penguins syncitial cell formation was present associated with degenerative changes and shrinkage of glomeruli. Two birds showed evidence of ureteritis with mixed inflammatory cells in the lumen of the proximal ureter. In another, the kidney showed an area of round cyst-like structures of uncertain aetiology. Slight urate nephrosis was present in 2 penguins.

Lesions possibly caused by 'puffinosis' are described below ('Examination for puffinosis').

The preen glands of all the penguins were examined for haemorrhage, because this had been found in many of the thin rockhoppers by observers in the Falklands during the 1986 mortality (Keymer 1987). However, no uropygial lesions were detected.

\section{Gross pathology and histopathology of penguins sacrificed in 1987}

Post-mortem examinations showed no gross or microscopical evidence of mycosis or reason to suspect any infectious disease relevant to the mortality of 1986. Gross pathological lesions were found in only 5 birds (all rockhoppers), 2 of which were obviously sick. In each bird the liver was primarily affected, with cysts present in 2 . In 1 bird, about a third of the organ showed multiple, discrete and partly confluent rounded cyst-like structures about $1 \mathrm{~cm}$ in diameter. These were surrounded by a fibrous capsule about $2 \mathrm{~mm}$ thick. The cyst contained greenish fluid and amorphous material. The bile ducts also appeared thickened. On histopathological examination some evidence was found of bile duct hyperplasia. The liver was congested, showing widespread perivascular cuffing by mononuclear cells. It also showed a superficial area of granulation tissue with vascularisation by small blood vessels, the presence of a few giant cells and considerable infiltration by mononuclears including lymphocytes and plasma cells. Especially near the surface of the lesion there was infiltration by fibroblasts. The other cystic liver was less severely affected and contained 1 fibrous walled cyst about $1 \mathrm{~cm}$ in diameter, containing clear fluid. Livers from 3 other birds merely showed yellowish or whitish, necrotic, focal lesions varying from 1 to $3 \mathrm{~mm}$ in diameter. On histopathological examination these were found to be microabscesses consisting of well-defined accumulations of granulocytes sometimes with giant cells in the centre. Some were subcapsular and others were deep in the parenchyma. However, using Gram's stain no bacteria were found associated with the lesions.

\section{Parasites}

Both ectoparasitism and endoparastism were found in the rockhoppers which died in 1986. Lice (?Austrogoniodes sp.) were found in the plumage of 14/15 $(93 \%)$ birds, and fleas (?Parapsyllus sp.) in one (6.6\%). However, it is likely that some ectoparasites dropped off the carcases.

During the field investigations in 1987, ectoparasites were found to be most common (7/12: $58 \%$ ) on Magellanic penguins, which unlike rockhoppers and gentoos nest in burrows and therefore are probably more at risk (Hawkey et al. 1989). Three (25\%) Magellanics were infested with ticks (Ixodes [Ceratixodes] urie, 
White, 1852, syn I. putus, Pickard, 1876); 2 (16.6\%) with lice (Austrogoniodes bifasciatus, Piaget, 1885); 1 (8.3\%) with fleas (?Parapsyllus sp.) and 1 (8.3\%) with unidentified feather mites. Three of the penguins had dual infestations and 1 bird had 3 types of parasites. Ectoparasitism in these Magellanic penguins may have been responsible for low haemoglobin and hypochromia (Hawkey et al. 1989).

Rockhoppers carried fewer (i.e. 4/32: 12.5\%) ectoparasites than those received during the 1986 mortality and also fewer than the Magellanic penguins. Ticks (Ixodes sp.) were found on 3 (9.4\%). Three species of lice were identified, namely Austrogoniodes macquariensis Harrison, 1937 sensu lato ${ }^{1}$; A. cristati Keler, 1952 and A. keleri Clay, 1967 on 4 (12.5\%). Fleas (Parapsyllus longicornis alginus Jordan, 1942) were found on only $2(6.2 \%)$. One rockhopper had a dual infestation and another had 3 types of parasites.

No ectoparasites were found on gentoos.

There was no evidence that helminthiasis was a contributory cause of death in the rockhoppers received in 1986, because only 3 birds (all adults) were infested. Acuarid nematodes (Synhaemantus sp.) were found in the stomach and cestodes (unidentifiable) in the intestine of 1 bird. In another rockhopper, helminth eggs (possibly physalopterid nematodes) were found in the bile ducts on histological examination. The intestinal tract of the third bird contained cestodes (Tetrabothrius eudyptidis Lonnberg, 1896) and unidentifiable nematode larvae.

In 1987, 54 penguins were examined for internal parasites, but helminths were found in only $7.4 \%$; all were adult Magellanics 4/12 (33\%).

No haematozoa were found in blood smears in any of the penguins, but they could have been missed, as no tissue impression smears were made.

\section{Examination for 'puffinosis'}

Lesions resembling 'puffinosis', as described and illustrated by Macdonald \& Conroy (1971) in gentoos, were found on the dorsal aspect of the feet, and less frequently on the legs, of 12/15 (80\%) rockhoppers received in 1986. Only 3/99 (3.0\%) collected in 1987 were affected; 1 from Sea Lion Island and 2 from New Island. The lesions were manifested as multiple discrete, rounded, slightly raised but superficial, yellowish brown lesions of dried exudate measuring from 2 to $3 \mathrm{~mm}$ in diameter. In 1 bird these were associated

\footnotetext{
${ }^{1}$ This denotes populations with a range of measurements and morphological variations at present considered different from the named species, but not sufficiently distinct to warrant the establishment of separate taxa
}

with rather indistinct, slightly purplish, erythematous patches of the skin. On histological examination the discrete lesions were found to be shallow ulcers. Necrosis of the epidermis was found, resulting in destruction of the keratinized layer. The necrosis extended in each case into the superficial areas of the dermis. The lesions were associated with bacteria and much granulocyte infiltration of the dermis beneath the necrotic areas. A foot lesion from the sick Sea Lion Island rockhopper showed more chronic changes, the epidermis and much of the dermis having been replaced by fibrous tissue. In some areas this was diffusely infiltrated by granulocytes. Gram-stained sections in each case failed to reveal the presence of any bacteria in association with the lesions. The histological lesions in these penguins were similar to the less advanced lesions described by Green (1965) in Manx shearwaters Puffinus puffinus. He also described acute epithelial 'blisters' which appear not to have been seen in penguins.

No inclusions or other lesions indicative of pox were found and examination by EM of lesions from 3 rockhoppers failed to show any virus particles.

No suspected 'puffinosis' foot lesions were seen in gentoos or Magellanic penguins.

\section{Toxicology}

The metal concentrations found in the penguin tissues in this study were of an order of magnitude similar to those reported in earlier studies. Copper and zinc are essential trace elements and should be homeostatically controlled within normal exposure concentrations, although these control mechanisms may break down at high exposures (Clarkson, 1979). Cadmium, mercury and lead are contaminants, although their source need not necessarily be anthropogenic.

Copper. Concentrations in the liver and kidneys of the gentoos and Magellanic penguins were approximately twice those found in the rockhoppers (Table 1). A possible explanation for this is that rockhoppers eat a higher proportion of crustaceans (e.g. euphausiids) in which, according to Prosser (1950), the copper content of their haemocyanin is lower than in molluscs (e.g. Loligo, Sepia and Octopus spp.). The concentrations in the Falkland rockhoppers were similar to those reported in this species from Gough Island, allowing for differences in dry (dw) and wet weight (ww) concentrations (Muirhead \& Furness 1988).

Zinc. Concentrations in all 3 species were similar, although those in the gentoos were slightly lower than in the other species (Table 1). Zinc concentrations reported in rockhoppers from Gough Island, South Atlantic, were similar to those reported in the present study, especially when the concentrations were ex- 
Table 1. Concentrations of metals in penguin tissues. All results expressed as $\mathrm{mg} \mathrm{kg}^{-1}$ dry weight, with the exception of those indicated ${ }^{*}$, which are expressed as wet weight. -: no data

\begin{tabular}{|c|c|c|c|c|c|c|c|c|}
\hline Species & Area/Date & Tissue & Copper & Zinc & Cadmium & Mercury & Lead & Source \\
\hline $\begin{array}{l}\text { Eudyptes } \\
\text { chrysocome }\end{array}$ & $\begin{array}{l}\text { Falklands } \\
1986\end{array}$ & Liver & $12.44 \pm 2.83$ & $119.22 \pm 35.16$ & $63.25 \pm 42.11$ & $\begin{array}{l}1.8 \text { to } 4.6 \\
\text { (range) }\end{array}$ & $0.62 \pm 1.04$ & This study \\
\hline $\begin{array}{l}\text { Eudyptes } \\
\text { chrysocome }\end{array}$ & $\begin{array}{l}\text { Falklands } \\
1986\end{array}$ & Kidney & $12.70 \pm 3.90$ & $103.04 \pm 35.16$ & - & - & - & This study \\
\hline $\begin{array}{l}\text { Eudyptes } \\
\text { chrysocome }\end{array}$ & $\begin{array}{l}\text { Falklands } \\
1987\end{array}$ & Liver & $15.00 \pm 4.71$ & $96.37 \pm 46.36$ & $65.64 \pm 50.02$ & $<2.2$ & $1.93 \pm 1.24$ & This study \\
\hline $\begin{array}{l}\text { Eudyptes } \\
\text { chrysocome }\end{array}$ & $\begin{array}{l}\text { Falklands } \\
1987\end{array}$ & Kidney & $18.17 \pm 6.80$ & $95.19 \pm 19.68$ & $107.01 \pm 51.03$ & - & $2.74 \pm 2.34$ & This study \\
\hline $\begin{array}{l}\text { Eudyptes } \\
\text { chrysocome }\end{array}$ & $\begin{array}{l}\text { Falklands } \\
1987\end{array}$ & Brain & - & - & $0.93 \pm 1.33$ & - & $0.81 \pm 0.46$ & This study \\
\hline $\begin{array}{l}\text { Eudyptes } \\
\text { chrysocome }\end{array}$ & $\begin{array}{l}\text { Gough } \\
\text { Island }\end{array}$ & Liver & $4.1 \pm 1.02^{*}$ & $40 \pm 11^{*}$ & $14 \pm 7.1^{*}$ & - & - & $\begin{array}{l}\text { Muirhead \& } \\
\text { Furness (1988) }\end{array}$ \\
\hline $\begin{array}{l}\text { Eudyptes } \\
\text { chrysocome }\end{array}$ & $\begin{array}{l}\text { Gough } \\
\text { Island }\end{array}$ & Kidney & $3.8 \pm 0.98^{*}$ & $63 \pm 16^{*}$ & $72 \pm 28^{*}$ & $2.3 \pm 0.94^{*}$ & - & $\begin{array}{l}\text { Muirhead \& } \\
\text { Furness (1988) }\end{array}$ \\
\hline $\begin{array}{l}\text { Pygoscellis } \\
\text { papua }\end{array}$ & $\begin{array}{l}\text { Falklands } \\
1987\end{array}$ & Liver & $36.98 \pm 16.8$ & $76.56 \pm 23.41$ & $96.78 \pm 81.04$ & - & $2.78 \pm 0.81$ & This study \\
\hline $\begin{array}{l}\text { Pygoscellis } \\
\text { papua }\end{array}$ & $\begin{array}{l}\text { Falklands } \\
1987\end{array}$ & Kidney & $22.37 \pm 8.71$ & $69.96 \pm 27.53$ & $207.38 \pm 175.35$ & - & $2.09 \pm 1.45$ & This study \\
\hline $\begin{array}{l}\text { Pygoscellis } \\
\text { papua }\end{array}$ & $\begin{array}{l}\text { Falklands } \\
1987\end{array}$ & Brain & - & - & $3.53 \pm 9.07$ & - & $1.04 \pm 0.87$ & This study \\
\hline $\begin{array}{l}\text { Pygoscellis } \\
\text { papua }\end{array}$ & Antarctica & Liver & - & - & - & $34.7 \pm 0.51$ & - & $\begin{array}{l}\text { Szefer et al. } \\
\text { (1993) }\end{array}$ \\
\hline $\begin{array}{l}\text { Pygoscellis } \\
\text { adeliae }\end{array}$ & $\begin{array}{l}\text { Aka Bay, } \\
\text { Weddell Sea } \\
\text { 1982/83 }\end{array}$ & Liver & $19.9 \pm 5.8$ & - & $7.5 \pm 2.4$ & - & - & Schneider (1986) \\
\hline $\begin{array}{l}\text { Pygoscellis } \\
\text { adeliae }\end{array}$ & $\begin{array}{l}\text { Aka Bay, } \\
\text { Weddell Sea } \\
\text { 1982/83 }\end{array}$ & Kidney & $17.8 \pm 4.1$ & - & $263.8 \pm 216.6$ & - & - & Schneider (1986) \\
\hline $\begin{array}{l}\text { Pygoscellis } \\
\text { adeliae }\end{array}$ & $\begin{array}{l}\text { Terra Nova } \\
\text { Bay, Antarctica }\end{array}$ & Liver & - & - & 14.5 & - & - & $\begin{array}{l}\text { Bargagli et al. } \\
\text { (1996) }\end{array}$ \\
\hline $\begin{array}{l}\text { Pygoscellis } \\
\text { adeliae }\end{array}$ & $\begin{array}{l}\text { Terra Nova } \\
\text { Bay, Antarctica }\end{array}$ & Kidney & - & - & 255 & - & - & $\begin{array}{l}\text { Bargagli et al. } \\
\text { (1996) }\end{array}$ \\
\hline $\begin{array}{l}\text { Pygoscellis } \\
\text { adeliae }\end{array}$ & Antarctica & Liver & - & - & - & 2.01 & - & $\begin{array}{l}\text { Szefer et al. } \\
\text { (1993) }\end{array}$ \\
\hline $\begin{array}{l}\text { Speniscus } \\
\text { magellanicus }\end{array}$ & $\begin{array}{l}\text { Falklands } \\
1987\end{array}$ & Liver & $24.97 \pm 25.42$ & $101.34 \pm 17.00$ & $106.67 \pm 41.26$ & - & $2.78 \pm 0.82$ & This study \\
\hline $\begin{array}{l}\text { Speniscus } \\
\text { magellanicus }\end{array}$ & $\begin{array}{l}\text { Falklands } \\
1987\end{array}$ & Kidney & $23.07 \pm 12.45$ & $109.84 \pm 23.41$ & $188.72 \pm 99.03$ & - & $1.31 \pm 0.75$ & This study \\
\hline $\begin{array}{l}\text { Speniscus } \\
\text { magellanicus }\end{array}$ & $\begin{array}{l}\text { Falklands } \\
1987\end{array}$ & Brain & - & - & $0.40 \pm 0.78$ & - & $0.75 \pm 0.35$ & This study \\
\hline $\begin{array}{l}\text { Megadyptes } \\
\text { antipodes }\end{array}$ & $\begin{array}{l}\text { New } \\
\text { Zealand }\end{array}$ & Liver & $3.47 \pm 0.17^{*}$ & $281 \pm 217^{*}$ & $1.27 \pm 0.04^{*}$ & $3.51 \pm 3.32^{*}$ & nd & $\begin{array}{l}\text { Gill \& Darby } \\
\text { (1993) }\end{array}$ \\
\hline $\begin{array}{l}\text { Aptenodytes } \\
\text { fosteri }\end{array}$ & $\begin{array}{l}\text { Atka Bay, } \\
\text { Weddell Sea, } \\
1983\end{array}$ & Liver & $23.4 \pm 4.0$ & - & $27.7 \pm 15.6$ & - & - & Schneider (1986) \\
\hline $\begin{array}{l}\text { Aptenodytes } \\
\text { fosteri }\end{array}$ & $\begin{array}{l}\text { Atka Bay, } \\
\text { Weddell Sea, } \\
1983\end{array}$ & Kidney & $19.1 \pm 3.0$ & - & $270.2 \pm 126.8$ & - & - & Schneider (1986) \\
\hline $\begin{array}{l}\text { Pygoscelis } \\
\text { antarctica }\end{array}$ & $\begin{array}{l}\text { Antarctica, } \\
1977-1979\end{array}$ & Liver & - & - & - & $0.48 \pm 0.20^{*}$ & - & $\begin{array}{l}\text { Norheim et al. } \\
\text { (1982) }\end{array}$ \\
\hline $\begin{array}{l}\text { Eudyptes } \\
\text { chrysolophus }\end{array}$ & $\begin{array}{l}\text { Antarctica, } \\
1977-1979\end{array}$ & Liver & - & - & - & $0.87 \pm 0.32^{*}$ & - & $\begin{array}{l}\text { Norheim et al. } \\
\text { (1982) }\end{array}$ \\
\hline
\end{tabular}


pressed as dw (Muirhead \& Furness 1988). The concentrations are well below those believed to be toxic to birds. There are no reports of zinc toxicity in penguins, but liver concentrations up to $417 \mathrm{mg} \mathrm{kg}^{-1} \mathrm{dw}$ were reported to be non-toxic to yellow-eyed penguins Megadyptes antipodes which had starved to death (Gill \& Darby 1993).

Cadmium. Concentrations in these penguins were high (Table 1), but not as high as the 270.2 $\pm 126.8 \mathrm{mg}$ $\mathrm{kg}^{-1} \mathrm{dw}$ reported in the kidney of Emperor penguins Aptenodytes forsteri sampled from the Weddell Sea in 1983 (Schneider, 1986). Higher cadmium concentrations were also reported by Muirhead \& Furness (1988) in 12 healthy rockhoppers from Gough Island, South Atlantic, taking into account differences in concentrations expressed as ww and dw. In the kidneys they recorded a mean and standard deviation of $72 \pm$ $28 \mathrm{mg} \mathrm{kg}^{-1} \mathrm{ww}$, a range of 32 to $112 \mathrm{mg} \mathrm{kg}^{-1} \mathrm{ww}$. The corresponding concentrations in the liver were $14 \pm$ $7.1 \mathrm{mg} \mathrm{kg}{ }^{-1}$ with a range of 4 to $26 \mathrm{mg} \mathrm{kg}^{-1}$ ww. Thresholds for cadmium toxicity have not been established in penguins, but renal toxicity has been reported in pelagic birds, i.e. puffins Fratercula arctica and Manx shearwaters which had renal concentrations ranging from 100 to $200 \mathrm{mg} \mathrm{kg}^{-1} \mathrm{dw}$ (Nicholson et al. 1983). Renal necrosis was reported in mallards Anas platyrhynchos which had kidney concentrations of 130 to $140 \mathrm{mg} \mathrm{kg}^{-1}$ ww. These ducks were exposed to dietary cadmium concentrations of $200 \mathrm{mg} \mathrm{kg}^{-1}$ for $60 \mathrm{~d}$ (White et al. 1978). Mallard ducklings were reported to be even more susceptible to cadmium with toxicity reported at $20 \mathrm{mg} \mathrm{kg}^{-1}$ diet (Cain et al. 1983).

Mercury. Concentrations found in penguins in this study (Table 1) are similar to those reported in other studies. Muirhead \& Furness (1988) reported a mean $( \pm \mathrm{SD})$ mercury concentration of $2.3 \pm 0.94 \mathrm{mg} \mathrm{kg}^{-1} \mathrm{ww}$ in 12 healthy rockhoppers sampled from Gough Island, South Atlantic. The mercury concentrations reported are well below the hepatic mercury concentration of $34.7 \mathrm{mg} \mathrm{kg}^{-1} \mathrm{dw}$ reported in gentoos (Szefer et al. 1993), which was reported to be of no concern, although Nicholson \& Osborn (1983) showed similar levels were associated with kidney lesions. There is evidence that mercury ingestion can cause renal damage. Juvenile starlings Sturnus vulgaris developed kidney lesions when given feed which was contaminated with mercury at $1.1 \mathrm{mg} \mathrm{kg}^{-1}$ with respective liver and kidney concentrations of $6.55 \pm 1.11,36.3 \pm 3.98 \mathrm{mg} \mathrm{kg}^{-1}$ dw (Nicholson \& Osborn 1984). This mercury was present in a commercial food source and may have been organic in nature, as it was probably derived from fish meal; birds inadvertently fed with this contaminated feed died within a few weeks (Osborn pers. comm.).

It is difficult to assess the significance of the mercury residues in the penguins from this study because the technique used to measure mercury did not determine mercury speciation. Many studies show that methylmercury predominates in marine species. However, both inorganic and organic mercury can have impacts on birds. Effects reported in birds exposed to inorganic mercury include delayed testicular development, gonadal atresia, reduced number of mating attempts and decreased fertility of eggs. There is more information on the toxicity of methyl mercury to birds, and effects include reproductive impairment due to reduced egg hatchability, reduced eggshell thickness and decreases in chick hatching weight and survival (WHO 1989).

Lead. Concentrations in all 3 species of penguins (Table 1) were below those thought to exert effects in birds (Scheuhammer 1987), although there were no previously reported lead concentrations in penguins on which to base a comparison. Contrary to the 'NEWS' item in Nature (Anonymous 1986) and the statement by Woods (1988), high concentrations of lead were not found in rockhopper penguins during the present investigation. Normal background concentrations in birds living in relatively uncontaminated areas are 1 to $10 \mathrm{mg} \mathrm{kg}^{-1} \mathrm{dw}$ and 0.5 to $5 \mathrm{mg} \mathrm{kg}^{-1} \mathrm{dw}$ for kidney and liver, respectively (Scheuhammer 1987).

Lead poisoning in most birds is manifested by gastrointestinal and neurological signs. It may be acute or chronic, depending upon the rate of exposure and the species. Chronic lead poisoning in a wild little penguin Eudyptula minor has been reported in Australia by Harrigan (1988). Analysis of liver and kidney revealed 27 and $107 \mathrm{mg} \mathrm{kg}^{-1}$ ww respectively. Pain (1996) classified lead concentrations in the liver of birds as follows, concentrations $<2 \mathrm{mg} \mathrm{kg}^{-1}$ ww were considered as background, 2 to $6 \mathrm{mg} \mathrm{kg}^{-1}$ ww were subclinical poisoning, 6 to $15 \mathrm{mg} \mathrm{kg}^{-1} \mathrm{ww}$ were clinical poisoning, with concentrations $>15 \mathrm{mg} \mathrm{kg}^{-1}$ ww indicative of severe clinical poisoning, and possible lethal effects. A diagnosis of lead toxicosis depends on histopathological findings and the concentration of lead in tissues.

Chromium. Attempts to detect chromium in the sick rockhoppers received in 1986 were unsuccessful. No analyses were therefore carried out on the 1987 birds.

Examination for radioactivity. None was detected.

\section{DISCUSSION}

\section{History}

There has been a continuous decline in the numbers of rockhopper penguins for many years in various parts of their range. Data collected from breeding colonies of penguins in the Falklands over a period of $10 \mathrm{yr}$ by 
Bingham (1995) suggested a decline in both rockhoppers and gentoos. Bingham (1998) carried out a further census in the austral summer of 1995-96 and concluded that rockhoppers appear to have declined by about $90 \%$ since a similar census in 1932-33. The figure for gentoos is approximately $43 \%$. There appears to have been a continuous decline throughout the period, suggesting that numbers of rockhoppers were falling before the population crash of 1985-86 and have continued to fall (Thompson 1993).

The history of widespread mortality of rockhoppers during the 1985-86 breeding season in the Falkland area strongly suggested that the primary cause was not due to an infectious agent (Keymer 1987).

Thompson (1989) studied the diet of a wide range of seabirds in the Falklands. She found that in rockhoppers during the egg laying and incubation periods euphausiids predominated in stomach contents: $60 \%$ by weight and over $95 \%$ by number of all food remains. Squid made up the majority of the remainder. However, during chick-rearing, the proportional weight of squid increased to about $50 \%$ although euphausiids were still overwhelmingly important numerically. The only period during which commercially exploited squid appeared in the samples in significant numbers was during moult. On the basis of these findings she concluded that 'during the breeding season there is little or no competition for resources between the fishery and rockhopper penguins'. The history of much less severe mortality in species other than rockhoppers, especially gentoo penguins, king shags Phalacrocorax atriceps albiventer and Antarctic skuas Catharacta antarctica may have had a similar aetiology. It is possible that the gentoos and shags were also mainly dependant on the same type and source of food as the rockhoppers.

The results of gross and histopathological examinations (see 'Results: Gross pathology and histopathology of rockhoppers in 1986') of the rockhoppers collected during the 1985-86 breeding season supported the hypothesis that the mortality was due to starvation. A large number of possible predisposing causes had been eliminated without reasonable doubt, namely: anthropogenic factors such as oiling; fish net mortality; ingestion of, or trauma from plastic artefacts (e.g. plastic beads in fish and plankton; plastic beer tin holders, rubber bands, elastic threads, fish hooks); trauma or trapping at sea or breeding grounds; effects of light ships or lighthouses; shooting; radioactivity from the 1982 Falklands war; organophosphate and organochlorine pesticide poisoning; and industrial polychlorinated biphenyl toxicity. Certain metal toxicities (not necessarily all anthropogenic in origin) were also excluded, i.e. copper, zinc, mercury, lead and chromium. Possible 'natural' causes were likewise eliminated such as: unusually heavy predation on or near breeding grounds by predatory birds or mammals such as seals, whales, and terrestrial carnivores; botulism at breeding grounds; and dinoflagellate poisoning caused by 'red tides'. Infectious diseases were investigated and considered in depth, and the following were eliminated without reasonable doubt: bacterial infections including chlamydiosis; mycoses; protozoan infections including haematozoa; helminthiasis; and viral infections. Specific examinations for some unlikely pathogens such as Rickettsiae or Mycoplasma spp. were not carried out in 1986. Certain viruses which cannot be detected using conventional techniques may also have been missed. No further attempt was made in 1987 to isolate viruses from the tissues of apparently healthy penguins, for example, by using cloacal swabs (Morgan 1988). Also, no attempt was made to investigate arthropod borne viral infections such as ticktransmitted flavivirus. The known tick vector Ixodes uriae was not confirmed on rockhoppers but was found on Magellanic penguins. A pathogenic strain of this virus has been isolated from ticks found on little penguins by Morgan et al. (1985).

\section{Uropygial haemorrhage}

This was noted by some observers in the rockhoppers dying during the 1986 mortality (Keymer 1987). There appear to be no other reports in wild penguins. It is not mentioned in the review of penguin diseases by Clarke \& Knowles (1993). The cause and significance are difficult to explain. It could have been due to pecking by birds such as skuas or even cannibalism by other rockhoppers. This lesion is well known in poultry and some other captive birds, but appears not to have been reported in free-living birds. In captivity it is not uncommon for sick, weakened birds to be attacked by their stronger companions. The rump is most accessible, especially when a bird is retreating from attack. Another possible cause of the haemorrhage was damage inflicted to the gland by the bird's beak, as the result of excessive preening caused by heavy ectoparasite infestations. The lesion was not observed in the healthy penguins in 1987. MacCoy \& Campbell (1991) have observed ruptured uropygial glands in captive gentoos.

\section{'Puffinosis'}

This is a mysterious disease which mainly inflicts Manx shearwaters on the islands of Skomer and Skokholm in Wales (UK). It can cause mortality, especially of fledglings. In the acute stage, the disease is 
characterised by 'blisters' (vesicles) on the feet, sometimes associated with conjunctivitis and paralysis of the legs (Brooke 1990). A similar syndrome has been recorded in other predominantly marine birds. Brooke (1990) stated that circumstantial, but not experimental, evidence points to the involvement of the harvest mite Neotrombiculus (syn. Trombiculus) autumnalis larvae in transmission.

In the sick penguins in 1986, the ulcers on the feet and tarsi closely resembled lesions of 'puffinosis' of shearwaters, but no mortality of penguin pulli (chicks) was reported associated with these lesions. A puffinosis-like syndrome causing mortality of gentoo penguin chicks, and to a lesser extent affecting adults, has been described and illustrated by Macdonald \& Conroy (1971). The foot lesions described and illustrated by them appear to be identical to those found in rockhoppers on the Falklands. It is apparently not known if Trombiculid mites occur on the Falklands, but Neotrombicula spp. (not including $N$. autumnalis) do occur on the mainland of South America. The foot lesions could conceivably have been caused by the larvae of these mites or other ectoparasites.

The disease, as described by Macdonald \& Conroy (1971), was undoubtedly present in some rockhoppers, and in association with starvation may possibly have been a secondary factor in the mortality.

\section{Undetected potentially toxic agents}

These are legion and it was clearly only possible to test for a limited number. It was decided therefore to concentrate on those to which it was thought penguins were most likely to be exposed. However, in retrospect there is no reason to suspect that any of relevance to the mortality have been missed.

\section{Cadmium toxicity}

It is necessary to consider the possible role of cadmium in the rockhopper mortality and also its significance at high concentrations in apparently healthy birds. High concentrations of this metal were found in the rockhoppers received for necropsy in 1986 and also in 3 species of apparently healthy penguins in 1987. It is interesting to note that the concentrations in healthy rockhoppers in 1987 were significantly lower than in healthy Magellanic and gentoos. Kate Thompson (pers. comm.) suggests that this may be because rockhoppers take more food from lower down in the food chain (i.e. krill) than the other 2 species, which eat more squid and fish and would therefore carry higher concentrations of the metal.
Laboratory toxicity studies on cadmium can relate toxic effects with exposure concentrations, although this becomes more difficult when dealing with wild animals whose cadmium exposure is more difficult to quantify. The critical cadmium concentration in experimental mammals is around 100 to $200 \mathrm{mg} \mathrm{kg}^{-1} \mathrm{ww}$, above which cadmium-induced nephropathy occurs (Scheuhammer 1987). Signs include proximal tubular cell necrosis, proteinurea, glycosuria, increased urinary cadmium, decreased cadmium in the kidney and metallothionein in the plasma. Similar findings have been reported in birds. Nicholson et al. (1983) reported kidney necrosis, degeneration of the proximal tubular epithelium and obstruction of the more distal nephron segments by necrotic cellular debris in pelagic birds with hepatic cadmium concentrations of 100 to $200 \mathrm{mg}$ $\mathrm{kg}^{-1} \mathrm{dw}$. These birds were puffins and Manx shearwaters which were sampled from St Kilda, off the west coast of Scotland.

In addition to direct toxicity, cadmium has also been reported to suppress egg production in mallards exposed to dietary concentrations of $200 \mathrm{mg} \mathrm{kg}^{-1}$ for $90 \mathrm{~d}$ (White \& Finley 1978).

Renal cadmium concentrations are generally higher than the hepatic cadmium concentrations in wild animals, and this was evident in the penguins in this study. A liver/kidney ratio of less than one is indicative of chronic rather than acute cadmium exposure (Scheuhammer 1987). Cadmium concentrations are known to increase with age and this may explain some of the inter-bird variability reported. Cadmium in the body is bound to metallothionein and this gives a long persistence in biological systems. The cadmium concentrations of eggs are low indicating that birds do not use this as a route of cadmium excretion (White \& Finley 1978).

In addition to the penguins of the present study, high cadmium concentrations have been reported in numerous Antarctic species representing various trophic levels. Bargagli et al. (1996) reported cadmium concentrations in phyto- and zooplankton and surface water sampled from Terra Nova Bay, Antarctica which were similar to concentrations measured in areas of enhanced upwelling. The cadmium concentration in the sediment from the same area was similar to background concentrations measured in most marine coastal areas. Malcolm et al. (1994) reported cadmium concentrations in the livers of Antarctic fur seals (Arctocephalus gazella) to range from 55.5 to $684 \mathrm{mg} \mathrm{kg}^{-1} \mathrm{dw}$. Although cadmium concentrations in Antarctic wildlife are often within the range regarded as potentially toxic, it is difficult to attribute the source to either natural or anthropogenic factors, as illustrated in the present study. It is even more difficult to demonstrate significant pathogenicity. For 
example, the cadmium concentrations in the livers of nearly half of the healthy 1987 rockhoppers were higher than the concentrations found in the 1986 bird with the lowest value, all but 2 starving penguins had concentrations higher than those found in healthy birds. The higher values for cadmium in most of the starving birds can be partly explained by the fact that the concentrations are expressed as a proportion of the tissue weight and these birds weighed considerably less than the healthy penguins in 1987. In addition it is suggested that the starving, and mainly postbreeding, adults in 1986 had mobilised the cadmium and other constituents from their bone marrow and other tissues, thus elevating the concentrations in the liver. Although the rockhopper carcases received in 1986 were sufficiently fresh for most examinations, the autolytic changes were too advanced to detect the type of renal tubular damage as described by Nicholson et al. (1983). Also, the majority of the penguins examined in 1987 appeared healthy and the plasma urate and urea concentrations (Ghebremeskel et al. 1989b) did not provide strong evidence of renal damage. It was therefore not considered necessary to carry out histological examinations of the kidneys from these birds. On the basis of the above factors it is thought that cadmium toxicity did not play a significant role in the 1985-86 mortality.

\section{Adverse environmental conditions}

These appear to be an important predisposing cause, at least for the 1985-86 breeding season and appear to have seriously affected the food supply of the rockhoppers in particular. Bourne (1986) stated that the southern summer of 1986 was unusually hot in the South Atlantic. Whilst at sea he noted that there was an influx of 'warm-water seabirds from the north'. In his experience more penguins fed inshore in 1986 than in 1985. He considered it was possible that the warm weather 'affected the growth or accessibility of their food at sea in the way that occurs when the warm current El Niño extends southwards off Peru in the Pacific'. Although there has been no repetition of an unusually hot summer in the Falklands since 1985-86, Bingham (pers. comm. 1999) found that in November 1998 most seabird breeding sites were adversely affected by unknown factors. Many adults were below weight at the start of the breeding seeason. Magellanic penguin numbers were down by about $16 \%$ and the population in 1999 was just one third of what it was 10 yr previously. Gentoos also decreased during the 1997-98 breeding season, but rockhoppers were in good condition at the start of the 1997-98 season and the population actually increased.

\section{CONCLUSIONS}

It seems likely that 'puffinosis' was merely a secondary factor in the rockhopper mortality during the 1985-86 breeding season. However, this syndrome in penguins needs further study. The concentrations of copper, zinc, mercury and lead measured in the 3 species of penguin in this study were below those currently thought to induce toxic effects. The concentrations of cadmium were within the range believed to cause nephrotoxic lesions. However, the kidney samples from the 1987 penguins were not examined for such lesions, because the birds appeared healthy. The kidneys of those which died in 1986 did not show any lesions of this type of toxicity, possibly because they were too autolysed. At least in the Falklands area, starvation was the primary cause of decline in breeding penguin numbers (especially rockhopper) during the 1985-86 breeding season. Since then populations of some species have continued to decline. Penguin and other seabird mortality is a very complex problem and a great deal more research is needed to assess to what extent it is related to adverse environmental conditions and over-exploitation of all forms of 'fish' stocks (i.e. Pisces and marine invertebrates).

Acknowledgements. In addition to the Falkland Island Government and the World Wildlife Fund (Worldwide Fund for Nature), which jointly financed the expedition to the Falklands, and the numerous people already mentioned in previous relevant publications; we are also very grateful to the following for their help in various ways: Dr C. D. Bracewell, Messrs P. Brown, T. Dell, S. Lister, J. Morris, P. Quick and P. Wyeth, Central Veterinary Laboratory, New Haw, Surrey; M. Fletcher, Central Science Laboratory, York; Mrs M. Haas, Institute of Terrestrial Ecology, Monks Wood, Cambridgeshire; M. Bingham, Environmental Research Unit, Ltd, Falkland Islands; Dr A. Leech, Holt, Norfolk; Mr A. D. Malley, Wickford, Essex; and Dr K. Thompson, previously Falklands Conservation, Stanley, Falkland Islands; and especially Mrs E. Borland, the senior author's colleague at the former Norwich Veterinary Investigation Centre.

\section{LITERATURE CITED}

Anonymous (1986) 'NEWS'. Falkland Islands. Nature 323:4

Bargagli R, Nelli L, Ancora S, Focardi S (1996) Elevated cadmium accumulation in marine organisms from Terra Nova Bay (Antarctica). Polar Biol 16:513-520

Bingham M (1995) Population status of penguin species in the Falkland Islands. Penguin Conserv 8(1):14-19

Bingham M (1998) The distribution, abundance and population trends of gentoo, rockhopper and king penguins in the Falkland Islands. Oryx 32(3):223-232

Boersma PD (1987) El Niño behind penguin deaths? Nature 327:96

Bourne WRP (1986) Penguin deaths questioned. Nature 322: 679

Brooke M (1990) Puffinosis, a mysterious disease. In: Brooke M (ed) The Manx shearwater. Academic Press, London, p 145-167 
Cain BW, Sileo L, Franson JC, Moore J (1983) Effects of dietary cadmium on mallard ducklings. Environ Res 32: 286-297

Clarke JR, Knowles RK (1993) Diseases and parasites of penguins. Korean J Polar Res 4 (2):79-96

Clarkson TW (1979) Effects - general principles underlying the toxic action of metals. In: Friberg L, Nordberg F, Vouk VB (eds) Handbook on the toxicology of metals. Elsevier/ North Holland Biomedical Press, Amsterdam, p 101

Ghebremeskel K, Williams G, Keymer IF, Horsley DT (1989a) Liver and plasma retinol (vitamin A) in wild, and liver retinol in captive penguins (Spheniscidae). J Zool Lond 219:245-250

Ghebremeskel K, Williams G, Keymer IF, Horsley DT Gardner DA (1989b) Plasma chemistry of rockhopper (Eudyptes crestatus), Magellanic (Spheniscus magellanicus) and gentoo (Pygoscelis papua) wild penguins in relation to moult. Comp Biochem Physiol 92A(1):43-47

Gill JM, Darby JT (1993) Short communication. Deaths in yellow-eyed penguins (Megadyptes antipodes) on the Otago Peninsula during the summer of 1990. NZ Vet J 41:39-42

Green GH (1965) Appendix. Histological examination of Manx Shearwater feet. Br Birds LVIII: 433-434

Harrigan KE (1988) Causes of mortality of Little Penguins. In: Australian wildlife, Vol 104. Postgraduate Committee in Veterinary Science, University of Sydney Proceedings, Sydney, p 2-12

Hawkey CM, Horsley DT, Keymer IF (1989) Haematology of wild penguins (Sphenisciformes) in the Falkland Islands. Avian Pathol 18:495-502

Karesh WB, Uhart MM, Frere E, Gandini P, Braselton WE, Puche H, Cook RA (1999) Health evaluation of freeranging rockhopper penguins (Eudyptes chrysocome) in Argentina. J Zoo Wildl Med 30(1):25-31

Keymer IF (1987) An investigation of rockhopper penguin (Eudyptes crestatus) mortality in the Falkland Islands during the 1985-1986 breeding season, Falkland Island Foundation Project Report, undertaken in collaboration with the Falkland Island Trust, p 1-19

MacCoy DM, Campbell TW (1991) Excision of impacted and ruptured uropygial glands in three gentoo penguins (Pygoscelis adeliae). 1991 Proc Am Assoc Zoo Vet, p 259-260

Macdonald JW, Conroy JWH (1971) Virus disease resembling puffinosis in the gentoo penguin (Pygoscelis papua) on Signy Island, South Orkney Islands. Br Antarct Sur Bull 26:80-82

Malcolm HM, Boyd IL, Osborn D, French MC, Freestone P (1994) Trace metals in Antarctic Fur Seal (Arctocephalus gazella) livers from Bird Island, South Georgia. Mar Pollut Bull 28(6):375-380

McPhaden MJ (1994) The eleven-year El Niño? Nature 370: 326

Morgan IR (1988) Viruses in Macquarie Island birds. Pap Proc R Soc Tasm 122(1):193-198

Morgan IR, Westbury HA, Campbell J (1985) Viral infections of Little Blue penguins (Eudyptula minor) along the southern coast of Australia. J Wildl Dis 21:193-198

Muirhead SJ, Furness RW (1988) Heavy metal concentrations in the tissues of seabirds from Gough Island, South Atlantic Ocean. Mar Pollut Bull 19:278-283

Nicholson JK, Osborn D (1983) Kidney lesions in pelagic seabirds with high tissue levels of cadmium and mercury. J Zool Lond 200:99-118

Editorial responsibility: Peernel Zwart,

Utrecht, The Netherlands
Nicholson JK, Osborn D (1984) Kidney lesions in juvenile starlings Sturnus vulgaris fed on a mercury contaminated synthetic diet. Environ Pollut 33:195-206

Nicholson JK, Kendall MD, Osborn D (1983) Cadmium and mercury nephrotoxicity. Nature 304:633-635

Norheim G, Somme L, Holt G (1982) Mercury and persistent chlorinated hydrocarbons in Antarctic birds from Bouvetoya and Dronning Maud Land. Environ Pollut 28: 233-240

Osborn D (1979) Season changes in the fat, protein and metal content of the liver of the starling, Sturnus vulgaris. Environ Pollut 19:145-155

Pain DJ (1996) Lead in waterfowl. In: Beyer WN, Heinz GH, Redmon-Norwood AW (eds) Environmental contaminants in wildlife: interpreting tissue concentrations. Lewis Publishers, Boca Raton, FL, p 251-264

Prosser CL (1950) Respiratory functions of body fluids. In: Prosser CL (ed) Comparative animal physiology. WB Saunders Company, Philadelphia, p 290-304

Ryan PG, Cooper J (1991) Rockhopper penguins and other marine life threatened by drift net fisheries at Tristan da Cunha. Oryx 25 (2):76-79

Samour HJ, Jones DM, Fitzgerald AK, Pugsley SL (1983) Blood sampling technique in penguins (Sphenisciformes). Vet Rec 113:340

Scheuhammer AM (1987) The chronic toxicity of aluminium, cadmium, mercury, and lead in birds: a review. Environ Pollut 46:263-295

Schneider G (1986) Cadmium and copper levels in seals, penguins and skuas from the Weddell Sea in 1982/1983. Polar Biol 5:139-143

Smith GR, Turner AM, Wynn-Williams DD, Collett G, Wright D, Keymer IF (1987) Search for Clostridium botulinum in the South Orkney and Falkland Islands. Vet Rec 121:404

Strange IJ (1982) Breeding ecology of the rockhopper penguin (Eudyptes crestatus) in the Falkland Islands. Gerfaut $72: 137-188$

Szefer P, Czarnowski W, Pempkowiak J, Holm E (1993) Mercury and major essential elements in seals, penguins and other representative fauna of the Antarctic. Arch Environ Contam Toxicol 25:422-427

Thompson KR (1989) An assessment of the potential for competition between seabirds and fisheries in the Falkland Islands. In: Thompson KR (ed) Falkland Islands Foundation Project Report. Falkland Islands Foundation, Brighton, p 19-21

Thompson KR (ed) (1993) Falkland Islands Seabird Monitoring Programme. Summary of Results 1989/90 to 1992/93. Falklands Conservation Report SMP/3. June 1993. Falklands Conservation, Stanley, p 1-24

White DH, Finley MT (1978) Uptake and retention of dietary cadmium in mallard ducks. Environ Res 17:53-59

White DH, Finley MY, Ferrell JF (1978) Histopathologic effects of dietary cadmium on kidneys and testes of mallard ducks. J Toxicol Environ Health 4:551-558

WHO (1989) Environmental health criteria 86 MercuryEnvironmental Aspects. World Health Organization, Geneva

Williams G, Ghebremeskel K, Keymer IF, Horsley DH (1989). Plasma $\alpha$-tocopherol, total lipids and total cholesterol in wild rockhopper, Magellanic and gentoo penguins before and after moulting. Vet Rec 124:585-586

Woods RW (ed) (1988) Introduction. Guide to birds of the Falkland Islands. Anthony Nelson Ltd, Oswestry, p 36

Submitted: Ausgust 17, 1999; Accepted: February 19, 2001

Proofs received from author(s): June 26, 2001 